\title{
Added dietary sulfur and molybdenum has a greater influence on hepatic copper concentration, intake, and performance in Holstein-Friesian dairy cows offered a grass silage- rather than corn silage-based diet
}

\author{
L. A. Sinclair, ${ }^{1}$ D. Johnson, ${ }^{2}$ S. Wilson, and A. M. Mackenzie \\ Department of Animal Production, Welfare and Veterinary Sciences, Harper Adams University, Edgmond, Newport, Shropshire, \\ United Kingdom TF10 8NB
}

\begin{abstract}
To test the hypothesis that the metabolism of $\mathrm{Cu}$ in dairy cows is affected by basal forage and added $\mathrm{S}$ and Mo, 56 dairy cows that were 35 (standard error \pm 2.2 ) days postcalving and yielding $38.9 \mathrm{~kg}$ of milk/d (standard error \pm 0.91 ) were offered 1 of 4 diets in a $2 \times 2$ factorial design for a 14 -wk period. The 4 diets contained approximately $20 \mathrm{mg}$ of $\mathrm{Cu} / \mathrm{kg}$ of dry matter (DM), and had a corn silage-to-grass silage ratio of 0.75:0.25 (C) or 0.25:0.75 (G) and were either unsupplemented $(-)$ or supplemented $(+)$ with an additional $2 \mathrm{~g}$ of $\mathrm{S} / \mathrm{kg}$ of DM and $6.5 \mathrm{mg}$ of $\mathrm{Mo} / \mathrm{kg}$ of DM. We found an interaction between forage source and added $\mathrm{S}$ and Mo on DM intake, with cows offered G+ having a 2.1 $\mathrm{kg}$ of DM lower intake than those offered $\mathrm{G}-$, but no effect on the corn silage-based diets. Mean milk yield was $38.9 \mathrm{~kg} / \mathrm{d}$ and we observed an interaction between basal forage and added $\mathrm{S}$ and Mo, with yield being decreased in cows offered $\mathrm{G}+$ but increased on $\mathrm{C}+$. No effect of dietary treatment on milk composition or live weight was noted, but body condition was lower in cows fed added S and Mo irrespective of forage source. We found an interaction between forage source and added $\mathrm{S}$ and Mo on milk somatic cell count, which was higher in cows offered $\mathrm{G}+$ compared with $\mathrm{G}-$, but not in cows fed the corn silage-based diets, although all values were low (mean values of $1.72,1.50,1.39$, and $1.67 \log _{10} / \mathrm{mL}$ for $\mathrm{C}-, \mathrm{C}+, \mathrm{G}-$, and $\mathrm{G}+$, respectively). Mean plasma $\mathrm{Cu}, \mathrm{Fe}$, and $\mathrm{Mn}$ concentrations were 13.8, 41.3, and $0.25 \mu \mathrm{mol} / \mathrm{L}$, respectively, and were not affected by dietary treatment, whereas plasma Mo was $0.2 \mu \mathrm{mol} / \mathrm{L}$ higher in cows receiving added $\mathrm{S}$ and Mo. The addition of dietary $\mathrm{S}$ and Mo decreased liver $\mathrm{Cu}$ balance over
\end{abstract}

\footnotetext{
Received October 27, 2016.

Accepted February 8, 2017.

${ }^{1}$ Corresponding author: lsinclair@harper-adams.ac.uk

${ }^{2}$ Current address: Faculty of Health and Social Sciences, Leeds Beckett University, Leeds, UK, LS1 3HE.
}

the study period in cows fed either basal forage, but the decrease was considerably greater in cows receiving the grass silage-based diet. Similarly, hepatic Fe decreased more in cows receiving $\mathrm{G}$ than $\mathrm{C}$ when $\mathrm{S}$ and Mo were included in the diet. We concluded that added $\mathrm{S}$ and Mo reduces hepatic $\mathrm{Cu}$ reserves irrespective of basal forage source, but this decrease is considerably more pronounced in cows receiving grass silage- than corn silage-based rations and is associated with a decrease in intake and milk performance and an increase in milk somatic cell count.

Key words: copper, corn silage, dairy cow, grass silage, liver

\section{INTRODUCTION}

It has long been recognized that $\mathrm{Cu}$ is an important trace element for normal health and performance in dairy cattle, principally due to its requirement in approximately 300 different proteins with functions ranging from efficient iron metabolism, hair pigmentation, antioxidants, release of hormones, and synthesis of connective tissue (Suttle, 2010). As a consequence, $\mathrm{Cu}$-responsive disorders result in production and economic losses due to effects on fertility, performance, and health (NRC, 2005). Clinical signs in dairy cows can be caused by a dietary deficiency of $\mathrm{Cu}$, but often are related to interactions with dietary antagonists such as $\mathrm{S}$ and $\mathrm{Mo}, \mathrm{Fe}$, and $\mathrm{Zn}$ that inhibit $\mathrm{Cu}$ absorption or metabolism (Suttle, 2010), with S and Mo receiving the most research attention. It has been proposed that dietary sulfates present in feed or water are reduced in the rumen to sulfides, which then react with molybdate to form thiomolybdates (Dick et al., 1975). Gould and Kendall (2011) discussed that thiomolybdates may be present in the rumen as di-, tri-, or tetrathiomolybdates, with trimolybdate predominant at a ruminal $\mathrm{pH}$ of 6.5 , whereas tetrathiomolybdate is most prevalent at lower $\mathrm{pH}$ values. Thiomolybdates form insoluble complexes with $\mathrm{Cu}$, rendering it unabsorbable (Suttle, 1991), resulting in Cu-responsive disorders. At high 
Mo intakes (e.g., $>8 \mathrm{mg}$ of $\mathrm{Mo} / \mathrm{kg}$ of $\mathrm{DM}$ ) and very low $\mathrm{Cu}$ :Mo ratios (less than 1:1), thiomolybdates may also leave the rumen and be absorbed (Suttle, 2010), subsequently binding to $\mathrm{Cu}$-containing enzymes such as ceruloplasmin $(\mathbf{C p})$, impairing their function (Gould and Kendall, 2011).

It is recognized that the degree of thiomolybdate formation in the rumen can also be affected by the basal forage and method of preservation (Suttle, 1974, 1983, 2010), although our understanding of the mechanism remains poor. For example, in grass hays, the inhibitory effect of $\mathrm{Mo}$ on $\mathrm{Cu}$ absorption is less than that of $\mathrm{S}$, whereas in fresh grass $\mathrm{Cu}$ absorption is greatly affected by small additions of $\mathrm{S}$ and Mo, with semipurified diets being intermediate (Suttle, 1983). A large body of literature exists comparing the effect of grass silage with corn silage on dairy cow intake and performance (e.g., Phipps et al., 1995; Hart et al., 2015), and, in general, replacing grass silage with corn silage results in an increase in DMI, milk yield, and milk protein content. However, little information is available on the relative effects of either of these forages on $\mathrm{Cu}$ metabolism in Holstein-Friesian dairy cows, despite their importance in contemporary dairy cow rations. A lack of understanding of the influence of $\mathrm{S}$ and $\mathrm{Mo}$ on $\mathrm{Cu}$ metabolism in dairy cows fed different forages may be contributing to the unnecessary oversupplementation of $\mathrm{Cu}$. Indeed, recent surveys of commercial trace element feeding rates in the United States and United Kingdom (e.g., Castillo et al., 2013; Sinclair and Atkins, 2015) have reported that dietary $\mathrm{Cu}$ is frequently fed at levels well above that recommended by national feed standards, such as ARC (1980) or NRC (2001). Feeding $\mathrm{Cu}$ above nutritional requirements can result in chronic $\mathrm{Cu}$ poisoning, whereby a gradual increase in hepatic $\mathrm{Cu}$ concentrations occurs, ultimately leading to rupture of lysosomes, hepatic necrosis, hemoglobinuria, methemoglobinemia, and rapid death (Bidewell et al., 2000). The objectives of our current study were to determine the effect of level of inclusion of corn silage and grass silage fed either without or with added sulfur and molybdenum on indicators of copper status, performance, and health in Holstein-Friesian dairy cows.

\section{MATERIALS AND METHODS}

\section{Animals, Management, and Treatments}

The procedures involving animals were conducted in accordance with the UK Animals (Scientific Procedures) Act (UK Parliament, 2012), and were approved by the Harper Adams Animal Welfare and Ethical Review Board. Fifty-six Holstein-Friesian dairy cows
(8 primiparous and 48 multiparous) that were 35 (SE $\pm 2.2) \mathrm{d}$ postcalving and yielding $38.9 \mathrm{~kg} / \mathrm{d}(\mathrm{SE} \pm 0.91)$ of milk were used. From calving until wk 5 of lactation the cows were group housed and fed a diet containing $95 \mathrm{~g} / \mathrm{kg}$ of DM of grass silage, $90 \mathrm{~g} / \mathrm{kg}$ of DM of alfalfa silage; $324 \mathrm{~g} / \mathrm{kg}$ of DM of corn silage; $20 \mathrm{~g} / \mathrm{kg}$ of DM of chopped wheat straw; $100 \mathrm{~g} / \mathrm{kg}$ of DM of urea-treated wheat; $80 \mathrm{~g} / \mathrm{kg}$ of DM of soy hulls; $50 \mathrm{~g} / \mathrm{kg}$ of DM of molasses; $66 \mathrm{~g} / \mathrm{kg}$ of DM of soybean meal; $64 \mathrm{~g} / \mathrm{kg}$ of DM of rapeseed meal; $64 \mathrm{~g} / \mathrm{kg}$ of DM of distillers grains; $18 \mathrm{~g} / \mathrm{kg}$ of DM of palm kernel meal; $14 \mathrm{~g} / \mathrm{kg}$ of DM of protected fat; and $15 \mathrm{~g} / \mathrm{kg}$ of DM of minerals and vitamins. Based on recordings taken in wk 4 of lactation the animals were blocked and allocated to 1 of 4 dietary treatments according to lactation number (primiparous or multiparous), calving date, milk yield, milk composition, BCS (using a 1-5 scoring system on a quarter point scale; Lowman et al., 1976), and live weight. Cows remained on study for 14 wk.

Based on the mineral analysis of the forages (Table 1) and NRC (2001) values for the other feeds, 4 diets were formulated to contain approximately $20 \mathrm{mg}$ of $\mathrm{Cu} / \mathrm{kg}$ of $\mathrm{DM}$ and a corn silage-to-grass silage ratio of 0.75:0.25 (C) or 0.25:0.75 (G; DM basis; Table 2). To evaluate the effects of dietary antagonists on $\mathrm{Cu}$ metabolism, the diets were either unsupplemented $(-)$ or supplemented $(+)$ with additional S and Mo, to result in a total dietary concentration of approximately $3.5 \mathrm{~g}$ of $\mathrm{S} / \mathrm{kg}$ of $\mathrm{DM}$ or $7.5 \mathrm{mg}$ of $\mathrm{Mo} / \mathrm{kg}$ of DM [an increase of approximately $2 \mathrm{~g}$ of $\mathrm{S} / \mathrm{kg}$ of DM $(+160 \%)$ and 6.5 $\mathrm{mg}$ of $\mathrm{Mo} / \mathrm{kg}$ of DM $(+500 \%)]$. Therefore, we used 4 dietary treatments: $\mathrm{C}-[0.75: 0.25$ corn silage:grass silage (DM basis), no additional antagonists]; $\mathrm{C}+(0.75: 0.25$ corn silage:grass silage, with additional $\mathrm{S}$ and $\mathrm{Mo}$ ); $\mathrm{G}-(0.25: 0.75$ corn silage;grass silage, no additional antagonists); and $\mathrm{G}+(0.25: 0.75$ corn silage:grass silage, with additional $\mathrm{S}$ and $\mathrm{Mo}$ ). Additional $\mathrm{Cu}$ was supplied as $\mathrm{CuSO}_{4} \cdot 5 \mathrm{H}_{2} \mathrm{O}$, sulfur as ammonium sulfate (TG Tennants, West Bromwich, United Kingdom), and molybdenum as sodium molybdate (Acros Organics, Geel, Belgium). Feed-grade urea was added to $\mathrm{G}-$ and $\mathrm{C}-$ to provide an equivalent amount of rumen-degradable $\mathrm{N}$ as supplied by the ammonium sulfate. The diets were supplemented with other feed ingredients to support a milk production of approximately $38 \mathrm{~kg} / \mathrm{d}$ according to Thomas (2004; Table 2). All dietary ingredients were mixed and fed as a TMR using a forage mixer calibrated to $\pm 1 \mathrm{~kg}$, and fed through roughage intake feeders (Hokofarm Group BV, Insentec, Marknesse, the Netherlands) fitted with an automatic animal identification and forage weighing system calibrated to \pm 0.1 $\mathrm{kg}$ (Sinclair et al., 2005). Fresh feed was offered daily at $105 \%$ of ad libitum intake with refusals collected twice 
Table 1. Chemical composition of corn and grass silage

\begin{tabular}{lcc}
\hline & $\begin{array}{c}\text { Corn } \\
\text { silage }\end{array}$ & $\begin{array}{c}\text { Grass } \\
\text { silage }\end{array}$ \\
\hline $\mathrm{DM}, \mathrm{g} / \mathrm{kg}$ & 341 & 256 \\
$\mathrm{CP}, \mathrm{g} / \mathrm{kg}$ of DM & 75 & 157 \\
Ash, g/kg of DM & 46 & \\
Ammonia-N, g/kg of total N & 9.03 & 8.39 \\
$\mathrm{pH}$ & 3.6 & 3.9 \\
$\mathrm{ME}, \mathrm{MJ} / \mathrm{kg}$ of DM & 10.8 & 11.2 \\
Water-soluble carbohydrate, g/kg of DM & 26.2 & 68.8 \\
NDF, g/kg of DM & 449 & 439 \\
ADF, g/kg of DM & 229 & 246 \\
VFA, g/kg of DM & & \\
Lactic & 62.1 & 105.3 \\
Acetic & 16.1 & 22.6 \\
Propionic & 0.92 & 1.06 \\
Butyric & $<0.6$ & $<0.6$ \\
Ethanol, g/kg of DM & 1.84 & 28.1 \\
Minerals & & \\
Ca, g/kg of DM & 2.3 & 7.3 \\
P, g/kg of DM & 2.3 & 3.3 \\
Mg, g/kg of DM & 1.5 & 1.7 \\
S, g/kg of DM & 0.9 & 3.1 \\
Cu, mg/kg of DM & 4.7 & 8.0 \\
Mo, mg/kg of DM & 0.59 & 1.43 \\
Fe, mg/kg of DM & 65.0 & 159.4 \\
Zn, mg/kg of DM & 23.6 & 37.8 \\
Mn, mg/kg of DM & 15.6 & 34.8 \\
\hline
\end{tabular}

weekly on a Tuesday and Friday. The cows were housed in the same portion of a freestall building containing freestalls fitted with foam mattresses. The passageways were scraped using automatic scrapers and the stalls bedded twice weekly with sawdust. All cows had continual access to fresh bore-hole water, which contained concentrations of $\mathrm{S}, \mathrm{Fe}, \mathrm{Cu}$, and $\mathrm{Mo}$ of $19.3 \mathrm{mg} / \mathrm{L}, 6.5$, 2.9 , and $0.5 \mu \mathrm{g} / \mathrm{L}$, respectively.

\section{Experimental Routine}

Cows were milked twice daily, at approximately 0530 and $1530 \mathrm{~h}$, with yield recorded at each milking and samples taken fortnightly at consecutive morning and afternoon milkings for subsequent composition and SCC analysis. The cows were weighed and BCS was recorded after the evening milking in the week before allocation, and then fortnightly afterward. Forage samples were collected weekly; half the sample was oven-dried at $70^{\circ} \mathrm{C}$ to constant weight, and the amount of corn silage to grass silage was adjusted to achieve the desired ratio. The other sample was frozen and bulked for subsequent analysis. Samples of each of the 4 diets were collected immediately following feeding once per week and stored at $-20^{\circ} \mathrm{C}$ before subsequent analysis. During wk 0,1 , $2,4,8$, and 14 of the study, blood samples were collected at $1000 \mathrm{~h}$ via jugular venipuncture into vacutainers (Becton Dickinson Vacutainer Systems, Plymouth, United Kingdom) containing silica (for samples used to determine $\mathrm{Cp}$ ), lithium heparin [for samples used to determine superoxide dismutase (SOD) activity], or sodium heparin (for samples used to determine mineral concentrations and metabolites). During wk 0 and 14 of the study, liver biopsy samples were collected from all cows through the 11th intercostal space, as described by Davies and Jebbett (1981), and stored at $-80^{\circ} \mathrm{C}$ before subsequent analysis.

\section{Chemical Analysis}

Weekly forage and TMR samples were bulked within month and analyzed according to AOAC International (2012) for DM (method 934.01), CP (method 990.03), and starch (method 920.40). In addition, forage samples were analyzed for $\mathrm{pH}$, ammonia-N, water-soluble carbohydrates (MAFF, 1986), and VFA based on the method of Jones and Kay (1976). The analysis of NDF and ADF were conducted according to Van Soest et al. (1991) with the use of a heat-stable $\alpha$-amylase (Sigma, Gillingham, UK), and expressed exclusive of residual ash. The ME content of the forages was determined by near infrared reflectance spectroscopy (Eurofins Laboratories, Wolverhampton, UK) using a system approved by United Kingdom advisory services (Offer et al., 1996). Forage and TMR minerals were extracted using the DigiPREP digestion system (Qmx Laboratories, Essex, UK), and analyzed as described by Cope et al. (2009) by inductively coupled plasma-MS (Thermo Fisher Scientific Inc., Hemel Hempstead, UK). Serum samples were analyzed for $\mathrm{Cp}$ according to Henry et al. (1974), and plasma samples for SOD (Randox Laboratories, Crumlin, UK; kit catalog no. SD 125), BHB, and urea (Randox Laboratories; kit catalog no. RB 1007 and UR221, respectively) using a Cobas Miras Plus autoanalyser (ABX Diagnostics, Bedfordshire, UK). Plasma and liver samples were analyzed for $\mathrm{Cu}$, $\mathrm{Fe}, \mathrm{Mn}$, and Mo by inductively coupled plasma-MS as described by Sinclair et al. (2013). Milk samples were analyzed using a Milkoscan Minor (FOSS, Warrington, UK) calibrated by the methods of AOAC International (2012), and SCC was determined by Eurofins Laboratories.

\section{Statistical Analysis}

Performance, plasma minerals, and metabolites were analyzed by repeated measures ANOVA as a $2 \times 2$ factorial design. Milk SCC was transformed to $\log _{10}$ before analysis. Treatment degrees of freedom were split into main effects of forage source (corn vs. grass silage), antagonist [without $(-)$ vs. with $(+)$ ] and their interaction and analyzed as 
Table 2. Diet composition and chemical analysis of diets high in corn silage (C) or grass silage (G) fed without $(-)$ or with $(+)$ added $\mathrm{S}$ and $\mathrm{Mo}^{1}$

\begin{tabular}{|c|c|c|c|c|}
\hline Item & $\mathrm{C}-$ & $\mathrm{C}+$ & G- & $\mathrm{G}+$ \\
\hline \multicolumn{5}{|l|}{ Ingredient, $\mathrm{g} / \mathrm{kg}$ of $\mathrm{DM}$} \\
\hline Grass silage & 133 & 134 & 398 & 399 \\
\hline Corn silage & 400 & 401 & 133 & 134 \\
\hline Urea-treated wheat & 111 & 111 & 167 & 167 \\
\hline Soy hulls & 89 & 89 & 89 & 89 \\
\hline Rapeseed meal & 58 & 58 & 31 & 31 \\
\hline Soybean meal & 96 & 96 & 31 & 31 \\
\hline Distillers dark grains with solubles & 58 & 58 & 31 & 31 \\
\hline Sopralin $^{2}$ & - & - & 58 & 58 \\
\hline Molasses & 33 & 33 & 33 & 33 \\
\hline Protected fat & 13 & 13 & 20 & 20 \\
\hline Urea & 2 & - & 2 & - \\
\hline Minerals/vitamins ${ }^{3}$ & 7 & 7 & 7 & 7 \\
\hline Total & 1,000 & 1,000 & 1,000 & 1,000 \\
\hline \multicolumn{5}{|l|}{ Chemical analysis } \\
\hline $\mathrm{DM}, \mathrm{g} / \mathrm{kg}$ & 404 & 421 & 364 & 368 \\
\hline Ash, $\mathrm{g} / \mathrm{kg}$ of $\mathrm{DM}$ & 71 & 71 & 92 & 93 \\
\hline $\mathrm{CP}, \mathrm{g} / \mathrm{kg}$ of $\mathrm{DM}$ & 181 & 185 & 193 & 194 \\
\hline $\mathrm{NDF}, \mathrm{g} / \mathrm{kg}$ of DM & 407 & 403 & 381 & 387 \\
\hline $\mathrm{ADF}, \mathrm{g} / \mathrm{kg}$ of $\mathrm{DM}$ & 222 & 224 & 228 & 224 \\
\hline $\mathrm{Ca}, \mathrm{g} / \mathrm{kg}$ of DM & 5.40 & 5.45 & 7.84 & 7.49 \\
\hline $\mathrm{P}, \mathrm{g} / \mathrm{kg}$ of $\mathrm{DM}$ & 3.57 & 3.82 & 3.96 & 3.69 \\
\hline $\mathrm{Mg}, \mathrm{g} / \mathrm{kg}$ of $\mathrm{DM}$ & 2.72 & 2.84 & 2.92 & 2.79 \\
\hline $\mathrm{S}, \mathrm{g} / \mathrm{kg}$ of $\mathrm{DM}$ & 1.20 & 3.15 & 1.32 & 3.45 \\
\hline $\mathrm{Cu}, \mathrm{mg} / \mathrm{kg}$ of $\mathrm{DM}$ & 19.9 & 19.5 & 20.7 & 20.5 \\
\hline Mo, mg/kg of DM & 1.17 & 7.94 & 1.48 & 7.70 \\
\hline $\mathrm{Fe}, \mathrm{mg} / \mathrm{kg}$ of $\mathrm{DM}$ & 183 & 226 & 287 & 252 \\
\hline $\mathrm{Zn}, \mathrm{mg} / \mathrm{kg}$ of $\mathrm{DM}$ & 49.2 & 46.3 & 51.8 & 48.8 \\
\hline $\mathrm{Mn}, \mathrm{mg} / \mathrm{kg}$ of $\mathrm{DM}$ & 61 & 68 & 70 & 60 \\
\hline
\end{tabular}

${ }^{1} \mathrm{C}+$ and $\mathrm{G}+$ diets also received additional ammonium sulfate and sodium molybdate dihydrate. SEM for differences between dietary concentrations ( $\mathrm{n}=8$ per treatment) for $\mathrm{S}$ and Mo was 0.11 and 0.29 , respectively.

${ }^{2}$ Formaldehyde-treated soybean meal, Frank Wright Trouw, Ashbourne, United Kingdom.

${ }^{3}$ Mineral/vitamin premix (Rumenco, Staffordshire, UK). Major minerals (g/kg): Ca, 240; P, 80; Mg, 120. Trace minerals (mg/kg): Cu, 0; Zn, 7,000; Mn, 2,000; I, 400; Co, 80; and Se, 50; vitamins (mg/kg): retinol, 105; cholecalciferol, 1.75; and all rac $\alpha$-tocopherol acetate, 5,000.

$$
\begin{gathered}
\mathrm{Y}_{\mathrm{ijkl}}=\mu+\mathrm{B}_{\mathrm{i}}+\mathrm{F}_{\mathrm{j}}+\mathrm{A}_{\mathrm{k}}+\mathrm{T}_{1}+\mathrm{F} \cdot \mathrm{A}_{\mathrm{jk}}+\mathrm{F} \cdot \mathrm{T}_{\mathrm{jl}} \\
+\mathrm{A} \cdot \mathrm{T}_{\mathrm{kl}}+\mathrm{F} \cdot \mathrm{A} \cdot \mathrm{T}_{\mathrm{jkl}}+\varepsilon_{\mathrm{ijkl}},
\end{gathered}
$$

where $Y_{\mathrm{ijkl}}=$ dependent variable; $\mu=$ overall mean; $\mathrm{B}_{\mathrm{i}}$ $=$ fixed effect of blocks; $F_{j}=$ effect of forage $(j=$ corn or grass silage); $\mathrm{A}_{\mathrm{k}}=$ effect of $\mathrm{S}$ and $\mathrm{Mo}(\mathrm{k}=-,+)$; $\mathrm{T}_{1}=$ effect of time; $\mathrm{F} \cdot \mathrm{A}_{\mathrm{jk}}=$ interactions between forage and antagonist; $\mathrm{F} \cdot \mathrm{T}_{\mathrm{jl}}=$ interaction between forage and time; $\mathrm{A} . \mathrm{T}_{\mathrm{kl}}=$ interaction between antagonist and time; F.A. $T_{j k l}=$ interaction between forage, antagonist, and time; and $\varepsilon_{\mathrm{ijkl}}=$ residual error.

Hepatic mineral concentration was analyzed by ANOVA as a $2 \times 2$ factorial design as

$$
\mathrm{Y}_{\mathrm{ijk}}=\mu+\mathrm{B}_{\mathrm{i}}+\mathrm{F}_{\mathrm{j}}+\mathrm{A}_{\mathrm{k}}+\mathrm{F} \cdot \mathrm{A}_{\mathrm{jk}}+\varepsilon_{\mathrm{ijk}},
$$

where $Y_{i j k}=$ dependent variable; $\mu=$ overall mean; $B_{i}$ $=$ fixed effect of blocks; $F_{j}=$ effect of forage $(j=$ corn or grass silage); $\mathrm{A}_{\mathrm{k}}=$ effect of $\mathrm{S}$ and $\mathrm{Mo}(\mathrm{k}=-,+) ; \mathrm{F} . \mathrm{A}_{\mathrm{jk}}$ $=$ interaction between forage and antagonist; and $\varepsilon_{\mathrm{ijk}}=$ residual error. For hepatic mineral concentrations, the concentration during wk 0 was used where appropriate as a covariate to determine the final and rate of mineral deposition or mobilization. All statistical analysis was conducted using Genstat version 17.1 (VSN Int. Ltd., Oxford, UK) and is presented as means with standard error of the mean; $P<0.05$ was used as the significant threshold and a trend was considered when $P<0.1$.

\section{RESULTS}

\section{Diet Analysis, Intake, and Animal Performance}

Compared with the corn silage, the grass silage contained $85 \mathrm{~g} / \mathrm{kg}$ less DM and was $82 \mathrm{~g} / \mathrm{kg}$ of DM higher in $\mathrm{CP}$ and $0.4 \mathrm{MJ} / \mathrm{kg}$ of DM higher in ME (Table 1). The 2 forages had a similar fiber content, but the grass silage was $43.2 \mathrm{~g} / \mathrm{kg}$ of DM higher in lactic acid than the corn silage. Compared with the corn silage, the mean content of $\mathrm{Ca}, \mathrm{P}, \mathrm{Mg}$, and $\mathrm{S}$ was $5.0,1.0,0.2$, and $2.2 \mathrm{~g} / \mathrm{kg}$ of DM higher, respectively, and $\mathrm{Cu}, \mathrm{Mo}$, 
Table 3. Intake and performance of early-lactation dairy cows fed diets high in corn silage $(\mathrm{C})$ or grass $(\mathrm{G})$ silage without $(-)$ or with $(+)$ added $\mathrm{S}$ and Mo

\begin{tabular}{|c|c|c|c|c|c|c|c|c|}
\hline \multirow[b]{2}{*}{ Item } & \multicolumn{4}{|c|}{ Diet } & \multirow[b]{2}{*}{ SEM } & \multicolumn{3}{|c|}{$P$-value ${ }^{1}$} \\
\hline & $\mathrm{C}-$ & $\mathrm{C}+$ & G- & $\mathrm{G}+$ & & $\mathrm{F}$ & $\mathrm{A}$ & Int \\
\hline $\mathrm{DM}, \mathrm{kg} / \mathrm{d}$ & 23.5 & 24.0 & 22.6 & 20.5 & 0.48 & $<0.001$ & 0.111 & 0.012 \\
\hline $\mathrm{Cu}, \mathrm{mg} / \mathrm{d}$ & 467 & 466 & 467 & 418 & 9.6 & 0.022 & 0.007 & 0.015 \\
\hline $\mathrm{Mo}, \mathrm{mg} / \mathrm{d}$ & 27.4 & 190.2 & 33.5 & 157.5 & 2.69 & $<0.001$ & $<0.001$ & $<0.001$ \\
\hline $\mathrm{S}, \mathrm{g} / \mathrm{d}$ & 28.1 & 74.9 & 29.9 & 70.4 & 1.25 & 0.302 & $<0.001$ & 0.013 \\
\hline Fat, $\mathrm{g} / \mathrm{kg}$ & 37.8 & 36.6 & 38.2 & 37.4 & 1.37 & 0.656 & 0.475 & 0.889 \\
\hline Protein, $\mathrm{g} / \mathrm{kg}$ & 32.5 & 32.6 & 31.6 & 32.5 & 0.80 & 0.173 & 0.901 & 0.646 \\
\hline Lactose, $\mathrm{g} / \mathrm{kg}$ & 46.5 & 46.4 & 46.7 & 46.3 & 0.32 & 0.975 & 0.328 & 0.680 \\
\hline Fat yield, $\mathrm{kg} / \mathrm{d}$ & 1.43 & 1.43 & 1.47 & 1.39 & 0.059 & 0.944 & 0.484 & 0.468 \\
\hline Protein yield, $\mathrm{kg} / \mathrm{d}$ & 1.23 & 1.30 & 1.22 & 1.21 & 0.024 & 0.049 & 0.242 & 0.142 \\
\hline Lactose yield, $\mathrm{kg} / \mathrm{d}$ & 1.77 & 1.93 & 1.80 & 1.73 & 0.063 & 0.185 & 0.434 & 0.060 \\
\hline Live weight, $\mathrm{kg}$ & 651 & 653 & 646 & 639 & 7.9 & 0.237 & 0.818 & 0.587 \\
\hline
\end{tabular}

${ }^{1} \mathrm{~F}=$ main effect of forage source, $\mathrm{A}=$ main effect of antagonists, Int = interaction between forage and antagonists.

Fe, and Zn were $3.3,0.84,94$, and $14.2 \mathrm{mg} / \mathrm{kg}$ of $\mathrm{DM}$ higher, respectively, in the grass silage.

The DM content of the corn based diets $(\mathrm{C}-$ and $\mathrm{C}+$ ) was $47 \mathrm{~g} / \mathrm{kg}$ higher than the grass silage-based diets $(\mathrm{G}-$ and $\mathrm{G}+$ ), whereas $\mathrm{CP}$ was on average 11 $\mathrm{g} / \mathrm{kg}$ of DM higher in the grass than the corn silagebased diets (Table 2). The content of NDF was higher in the corn than the grass silage-based diets, but ADF concentration was similar across all 4 diets, averaging $225 \mathrm{~g} / \mathrm{kg}$ of DM. All 4 diets had a similar $\mathrm{P}$ and $\mathrm{Mg}$ concentration, but the grass silage-based diets $(\mathrm{G}-$ and $\mathrm{G}+$ ) contained approximately $2 \mathrm{~g} / \mathrm{kg}$ of DM more Ca. The mean concentration of $\mathrm{Cu}$ was $20 \mathrm{mg} / \mathrm{kg}$ of DM, and the 2 diets with added antagonists $(\mathrm{C}+$ and $\mathrm{G}+$ ) had concentrations of $\mathrm{S}$ and Mo of $3.3 \mathrm{~g} / \mathrm{kg}$ of DM and $7.8 \mathrm{mg} / \mathrm{kg}$ of DM, respectively, which were close $(P>0.05)$ to the predicted values of $3.5 \mathrm{~g} / \mathrm{kg}$ of DM and $7.5 \mathrm{mg} / \mathrm{kg}$ of $\mathrm{DM}$, respectively. In contrast, the 2 diets with no added $\mathrm{S}$ and $\mathrm{Mo}(\mathrm{C}-$ and $\mathrm{G}-$ ) had low concentrations of $\mathrm{S}$ and Mo, at $1.3 \mathrm{~g} / \mathrm{kg}$ of DM and 1.3 $\mathrm{mg} / \mathrm{kg}$ of DM, respectively, that were also close $(P>$ 0.05) to predicted.

Cows offered the corn silage-based diets had a daily DMI that was $2.2 \mathrm{~kg} / \mathrm{d}$ higher $(P<0.001)$ than those offered the grass silage-based diets (Table 3 ), an effect that was evident from wk 1 of the study (Figure 1). We noted an interaction $(P<0.05)$ between forage source and $\mathrm{Cu}$ antagonists, where adding $\mathrm{S}$ and Mo reduced DMI by $2.1 \mathrm{~kg} / \mathrm{d}$ in cows fed the grass silage- but not the corn silage-based diet. We also found an interaction between forage source and antagonist on $\mathrm{Cu}$ intake, which was lowest $(P<0.05)$ in cows fed $\mathrm{G}+$ compared with the other 3 treatments. An interaction $(P<0.05)$ between forage source and $\mathrm{Cu}$ antagonists on milk yield was observed, with yield decreasing with the addition of $\mathrm{S}$ and Mo in cows fed the grass silage-based diet but increasing in those offered the corn silage-based diet. In contrast, we found no effect $(P>0.05)$ of dietary treatment on milk fat, protein, or lactose content or daily fat yield, but we found that daily milk protein yield was $0.05 \mathrm{~kg} / \mathrm{d}$ higher $(P<0.05)$ in cows fed the corn silage-based diet. We found no effect $(P>0.05)$ of dietary treatment on live weight or daily live weight change, but an effect of antagonist on BCS and BCS change $(P<0.05)$, with cows fed added $\mathrm{S}$ and $\mathrm{Mo}(\mathrm{C}+$ and $\mathrm{G}+$ ) having a lower score and gaining less BCS over the study period than those not supplemented with $\mathrm{S}$ and Mo (C- and $\mathrm{G}$-; Figure 2). We observed an interaction $(P<0.05)$ between forage source and $\mathrm{Cu}$ antagonists on milk SCC count, with the addition of S and Mo increasing SCC in cows fed the grass silage- but not the corn silage-based diet.

\section{Plasma Mineral Profile, Cu-Mediated Enzymes, and Metabolites}

We found no effect $(P>0.05)$ of dietary treatment on plasma $\mathrm{Cu}$ concentration, with a mean value of 13.7 $\mu \mathrm{mol} / \mathrm{L}$ (Table 4). An effect of time on plasma $\mathrm{Cu}$ was noted, with the concentration increasing in the first week of the study and then fluctuating in subsequent weeks (Figure 3$)$. We also found an effect $(P<0.001)$ of dietary treatment on mean plasma Mo concentrations, which were higher in cows fed added $\mathrm{S}$ and Mo, but 


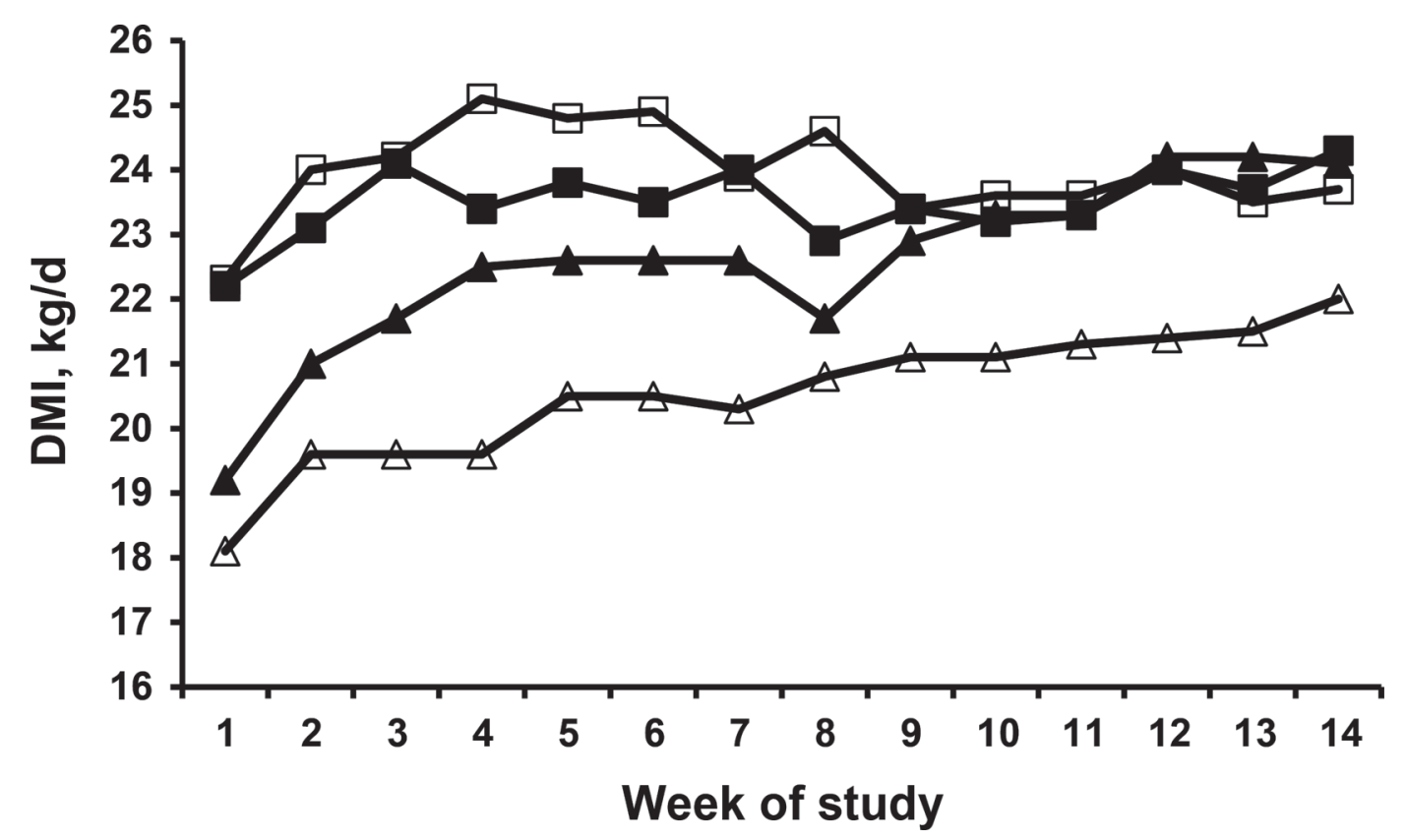

Figure 1. Weekly DMI in early-lactation dairy cows fed diets high in corn silage without $(\mathbf{\square})$ or with ( $\square)$ added $\mathrm{S}$ and Mo, or diets high in grass silage without $(\mathbf{\Lambda})$ or with $(\Delta)$ added $\mathrm{S}$ and Mo. Pooled SEM $=0.72$. Forage, $P<0.001$; forage $\times$ antagonist, $P=0.012 ;$ time, $P<0.001$; forage $\times$ time, $P=0.003$.

observed no effect $(P>0.05)$ of basal forage. We noted no effect $(P>0.05)$ of dietary treatment on plasma Fe or Mn concentrations. Serum Cp concentrations were higher $(P<0.01)$ in cows fed the grass silage-based diets or with added $\mathrm{S}$ and $\mathrm{Mo}(P<0.05)$. In contrast, we found no effect of dietary treatment on blood $\mathrm{Cp}-$ to- $\mathrm{Cu}$ ratio, although a trend $(P<0.1)$ was noted for a lower ratio in cows fed the corn silage-based diets

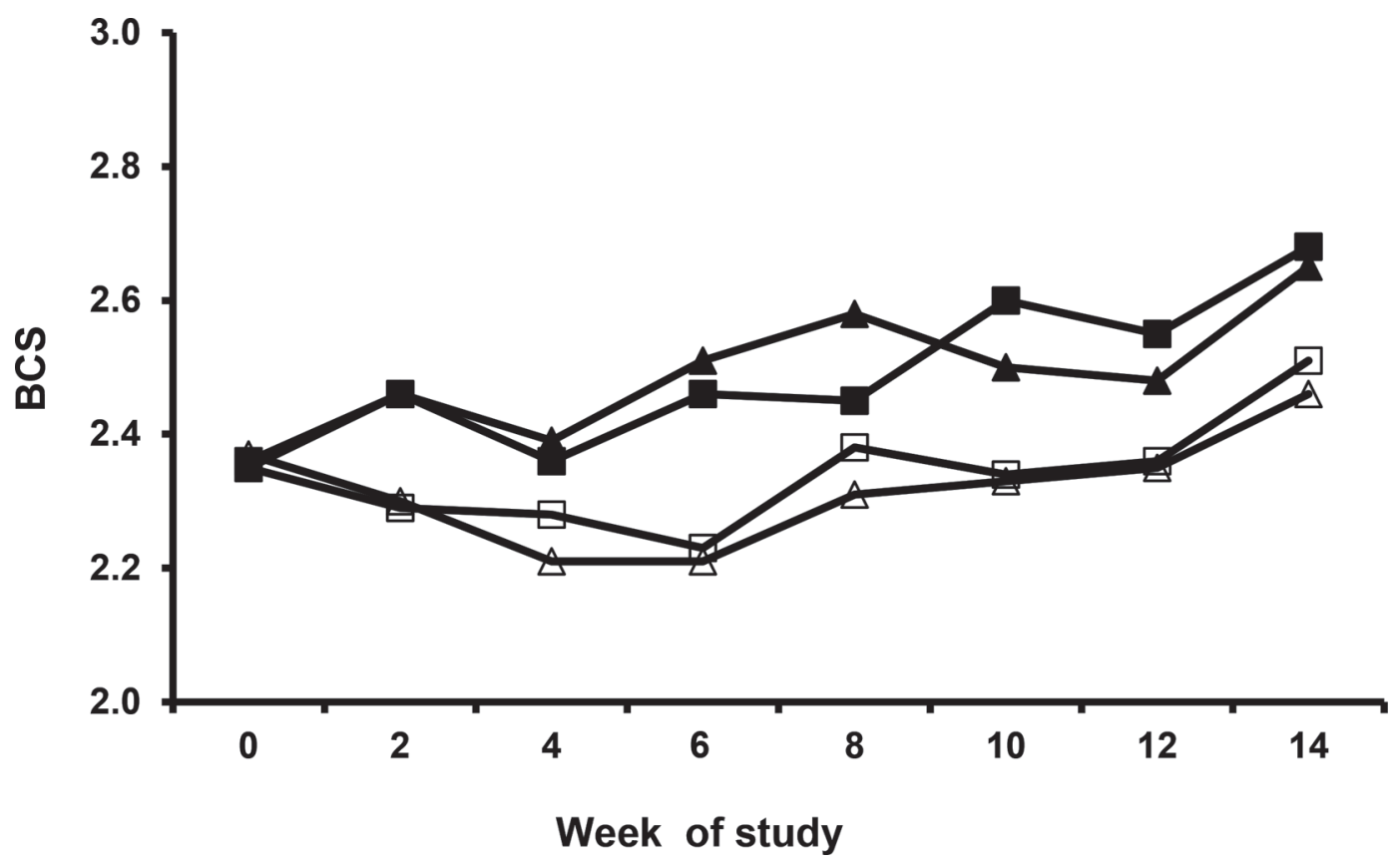

Figure 2. Fortnightly BCS in early-lactation dairy cows fed diets high in corn silage without $(\mathbf{\square})$ or with ( $\square$ ) added S and Mo, or diets high in grass silage without $(\mathbf{\Delta})$ or with $(\triangle)$ added $\mathrm{S}$ and Mo. Pooled SEM $=0.067$. Antagonist, $P<0.001 ;$ time, $P<0.001 ;$ time $\times$ antagonist, $P$ $=0.077$. 
Table 4. Plasma mineral concentration and metabolites and serum ceruloplasmin in early-lactation dairy cows fed diets high in corn silage (C) or grass silage $(\mathrm{G})$ without $(-)$ or with $(+)$ added $\mathrm{S}$ and Mo ${ }^{1}$

\begin{tabular}{|c|c|c|c|c|c|c|c|c|}
\hline \multirow[b]{2}{*}{ Item } & \multicolumn{4}{|c|}{ Diet } & \multirow[b]{2}{*}{ SEM } & \multicolumn{3}{|c|}{$P$-value ${ }^{2}$} \\
\hline & $\mathrm{C}-$ & $\mathrm{C}+$ & $\mathrm{G}-$ & $\mathrm{G}+$ & & F & $\mathrm{A}$ & Int \\
\hline Plasma Mo, $\mu \mathrm{mol} / \mathrm{L}$ & 0.33 & 0.50 & 0.27 & 0.50 & 0.029 & 0.271 & $<0.001$ & 0.375 \\
\hline Plasma Fe, $\mu \mathrm{mol} / \mathrm{L}$ & 43.2 & 40.5 & 40.7 & 40.9 & 1.61 & 0.519 & 0.446 & 0.384 \\
\hline Plasma Mn, $\mu \mathrm{mol} / \mathrm{L}$ & 0.25 & 0.24 & 0.27 & 0.25 & 0.010 & 0.124 & 0.239 & 0.740 \\
\hline Ceruloplasmin, mg/dL & 17.9 & 15.9 & 20.3 & 18.1 & 0.79 & 0.006 & 0.010 & 0.909 \\
\hline $\mathrm{BHB}, \mathrm{mmol} / \mathrm{L}$ & 0.42 & 0.38 & 0.44 & 0.48 & 0.048 & 0.210 & 0.963 & 0.406 \\
\hline $\mathrm{BUN}, \mathrm{mmol} / \mathrm{L}$ & 5.22 & 5.44 & 5.70 & 5.39 & 0.189 & 0.265 & 0.802 & 0.172 \\
\hline
\end{tabular}

${ }^{1}$ Blood samples were collected during wk $0,1,2,4,8$ and 14 of the study.

${ }^{2} \mathrm{~F}=$ main effect of forage source, $\mathrm{A}=$ main effect of antagonists, Int = interaction between forage and antagonists. We noted time $\times$ treatment effect on plasma Mo $(P<0.05)$, which increased with time in animals receiving $\mathrm{C}+$ and $\mathrm{G}+$ compared with $\mathrm{C}-$ and $\mathrm{G}-$.

${ }^{3} \mathrm{SOD}=$ superoxide dismutase.

or in animals receiving added $\mathrm{S}$ and Mo. We observed no effect $(P>0.05)$ of dietary treatment on plasma $\mathrm{SOD}, \mathrm{BHB}$, or BUN concentrations, with mean values of $2918 \mathrm{U} / \mathrm{g}$ of $\mathrm{Hb}, 0.43 \mathrm{mmol} / \mathrm{L}$, and $5.44 \mathrm{mmol} / \mathrm{L}$, respectively.

\section{Hepatic Mineral Concentration}

We found no difference between dietary treatments $(P>0.05)$ in initial hepatic $\mathrm{Cu}$ concentration, which averaged $443 \mathrm{mg} / \mathrm{kg}$ of DM (Table 5). We did find an effect of forage source on final $\mathrm{Cu}$ concentration, which was higher $(P<0.05)$ in cows fed the corn silage- compared with the grass silage-based diets. An effect of $\mathrm{Cu}$ antagonists on final hepatic $\mathrm{Cu}$ concentration was also noted, which was $142 \mathrm{mg} / \mathrm{kg}$ of DM lower $(P<0.01)$ in cows fed added $\mathrm{S}$ and Mo. We observed a trend $(P$ $<0.1$ ) for an interaction between forage source and $\mathrm{Cu}$ antagonists on the rate of change in hepatic $\mathrm{Cu}$ concentration, with a decrease of $61 \mathrm{mg} / \mathrm{kg}$ of DM over the 14-wk study period in cows fed added $\mathrm{S}$ and Mo in combination with grass silage $(\mathrm{G}+)$, but an increase of $11 \mathrm{mg} / \mathrm{kg}$ of DM in cows offered the corn silage-based $\operatorname{diet}(\mathrm{C}+)$.

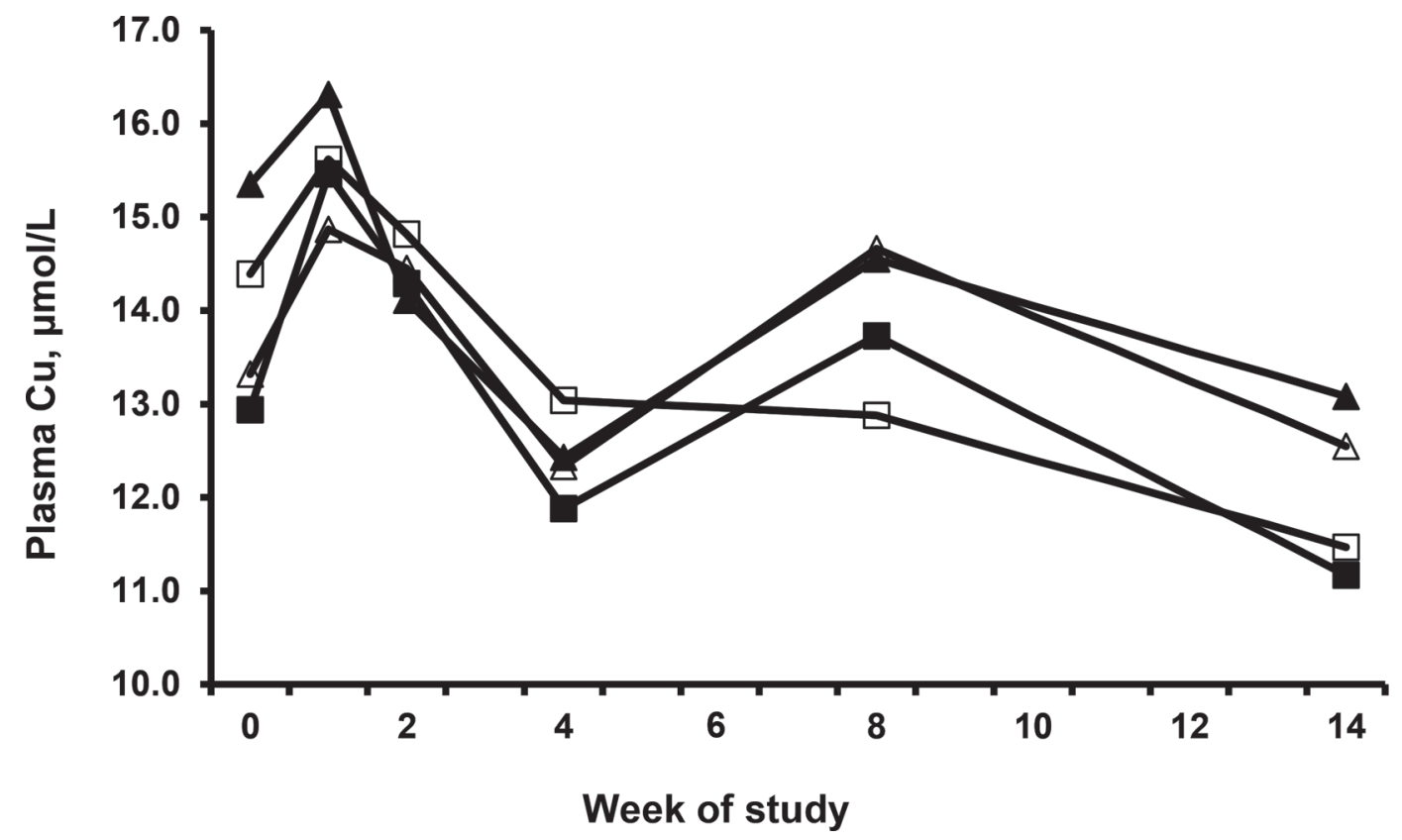

Figure 3. Plasma $\mathrm{Cu}$ concentrations in early-lactation dairy cows fed diets high in corn silage without ( diets high in grass silage without $(\boldsymbol{\Delta})$ or with $(\Delta)$ added $\mathrm{S}$ and Mo. Pooled SEM $=0.87$. Time, $P<0.001$. 
Table 5. Liver mineral concentrations in early-lactation dairy cows fed diets high in corn silage $(\mathrm{C})$ or grass silage $(\mathrm{G})$ without $(-)$ or with $(+)$ added $\mathrm{S}$ and Mo

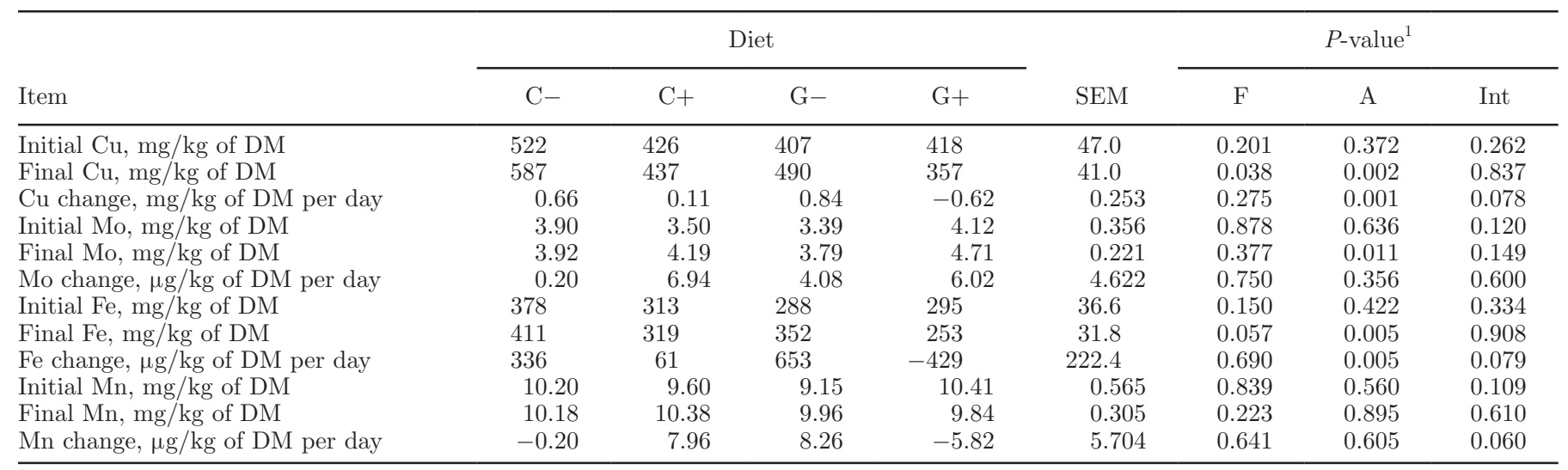

${ }^{1} \mathrm{~F}=$ main effect of forage source, $\mathrm{A}=$ main effect of antagonists, Int = interaction between forage and antagonists.

We found no difference between treatments in initial hepatic Mo concentration $(P>0.05)$, whereas final Mo concentration was higher $(P<0.05)$ in cows fed added $\mathrm{S}$ and $\mathrm{Mo}(\mathrm{C}+$ and $\mathrm{G}+)$. Initial hepatic Fe concentration did not differ between treatments $(P>0.05)$, whereas final concentration was lower $(P<0.01)$ in cows fed added $\mathrm{S}$ and Mo, and a trend $(P<0.1)$ for final hepatic Fe concentration to be higher was found in cows offered the corn silage- compared with the grass silage-based diet. The addition of $\mathrm{S}$ and Mo resulted in a net decrease in hepatic Fe concentration over the study period of $19 \mathrm{mg} / \mathrm{kg}$ of DM compared with an increase in cows that were not supplemented with $\mathrm{S}$ and Mo of $50 \mathrm{mg} / \mathrm{kg}$ of DM, although most of this difference could be attributed to cows fed the grass silage-based ration with added $\mathrm{S}$ and Mo $(\mathrm{G}+)$ decreasing in hepatic $\mathrm{Fe}$ concentration $(P<0.1)$ compared with an increase in cows fed any of the other dietary treatments. Finally, we found no effect $(P<0.05)$ of dietary treatment on hepatic Mn concentrations, although cows fed the grass silage with $\mathrm{Cu}$ antagonists $(\mathrm{G}+)$ tended $(P<0.1)$ to decrease by the greatest amount.

\section{DISCUSSION}

\section{Intake and Performance}

Our study is the first to determine $\mathrm{Cu}$ status and metabolism in high-yielding dairy cows when fed corn silage- or grass silage-based rations at different $\mathrm{S}$ and Mo concentrations. Corn silage is generally regarded as having a lower $\mathrm{Cu}$ concentration than grass silage (NRC, 2001), but we supplemented the diets to ensure that levels were similar across all treatments, averaging $20.0 \mathrm{mg}$ of $\mathrm{Cu} / \mathrm{kg}$ of DM. The dietary level of $20 \mathrm{mg}$ of $\mathrm{Cu} / \mathrm{kg}$ of $\mathrm{DM}$ was lower than the mean value of 27.9 $\mathrm{mg} / \mathrm{kg}$ of DM per day that was reported in the diet of early-lactation cows in the United Kingdom (Sinclair and Atkins, 2015), but similar to the $18 \mathrm{mg} / \mathrm{kg}$ of DM reported on 39 Californian dairy units by Castillo et al. (2013). Additionally, we added $\mathrm{S}$ and Mo at a rate to ensure that the supplemented $\operatorname{diets}(\mathrm{C}+$ and $\mathrm{G}+)$ had similar concentrations, which would be expected to substantially reduce $\mathrm{Cu}$ absorption and subsequent metabolism. Differences in dietary S and Mo concentration between diets within the same level of antagonist was small $(P>0.05)$, and therefore the main effect was the difference between the unsupplemented and supplemented diets. Using the equations of Suttle and McLauchlin (1976), we predicted that the C- and Gdiets would result in an apparent absorption coefficient of $\mathrm{Cu}$ of approximately 0.054 , whereas the $\mathrm{C}+$ and $\mathrm{G}+$ diets would be two-thirds lower at approximately 0.018 . As a consequence, we predicted that animals receiving $\mathrm{C}$ - or $\mathrm{G}$ - had a similar Cu supply but were over supplied by approximately $220 \mathrm{mg}$ of $\mathrm{Cu} / \mathrm{d}$, whereas those receiving $\mathrm{C}+$ or $\mathrm{G}+$ were undersupplied by approximately $200 \mathrm{mg}$ of $\mathrm{Cu} / \mathrm{d}$. However, the use of the current equations did not predict any interaction between forage source and antagonist on $\mathrm{Cu}$ status or performance.

Similar to other studies that have investigated the effect of replacing grass silage with corn silage (Phipps et al., 1995; Hart et al., 2015), we found that DMI was increased at the higher corn inclusion rate, although it is accepted that the change in forage composition from the prestudy diet was greater for cows on $\mathrm{G}$ than $\mathrm{C}$ diets. However, we also found an interaction between forage inclusion level and $\mathrm{Cu}$ antagonists on intake, with added $\mathrm{S}$ and Mo having little effect in cows fed the corn silage-based diet but reduced intake by $2.1 \mathrm{~kg}$ of DM/d in those receiving the grass silage-based diet. Our diets were supplemented with both $\mathrm{S}$ and Mo, and it is 
therefore not possible to determine the effects of each element independently. Some authors have reported a decrease in DMI in cattle when dietary $\mathrm{S}$ exceeded 2 $\mathrm{g} / \mathrm{kg}$ of DM (Spears et al., 2011), although others have reported little effect of dietary $\mathrm{S}$ concentration up to 6 $\mathrm{g} / \mathrm{kg}$ of DM (Richter et al., 2012). Under acidic ruminal conditions, most of the $\mathrm{S}$ would be present as $\mathrm{H}_{2} \mathrm{~S}$, which may be eructated and absorbed by the lungs or absorbed across the rumen epithelium (Bray and Till, 1975; Drewnoski et al., 2012). High circulating concentrations of $\mathrm{H}_{2} \mathrm{~S}$ can have neurological effects, including polioencephalomalacia, which is associated with a reduced intake (Gould, 1998). The large role that ruminal $\mathrm{pH}$ plays in the form of sulfide present in the rumen has been suggested as a possible explanation for the differences observed in sulfur tolerance between concentrate and roughage fed cattle (Drewnoski et al., 2012), and could explain the reduced DMI of cows offered G+ in our study. However, we did not monitor ruminal $\mathrm{H}_{2} \mathrm{~S}$ or $\mathrm{pH}$ levels, and the influence of level of inclusion of corn and grass silage on ruminal $\mathrm{pH}$ is difficult to predict, as it is dependent on several factors including initial forage $\mathrm{pH}$, buffering capacity of the diet, forage particle length, and supplementary feed level, composition, and degree of processing (Krause and Oetzel, 2006).

Molybdenum interacts with S in the rumen, resulting in the formation of various isomers of thiomolybdate, a reaction that is reversible and $\mathrm{pH}$-dependent, with the formation of tetra-thiomolybdate being favored at lower ruminal $\mathrm{pH}$ values (Gould and Kendall, 2011). Indeed, the dietary addition of Mo has been proposed as a potential sink for $\mathrm{H}_{2} \mathrm{~S}$ in the rumen (Kessler et al., 2012), potentially reducing the negative effects of excess dietary $\mathrm{S}$ on intake, although this approach has not been supported by recent studies with beef animals (Kessler et al., 2012). An alternative hypothesis for the effect of added S and Mo on intake may be related to the absorption of tetra-thiomolybdates, as these can have a direct effect on $\mathrm{Cu}$ containing enzymes such as peptidylglycine $\alpha$-amidating monooxygenase, which exerts an influence on the appetite-regulating hormones cholecystokinin and gastrin (Suttle, 2010), although studies in this area in ruminants are scarce. Ruminal absorption of tetra-thiomolybdates is increased at lower ruminal $\mathrm{pH}$ values, and it is possible that differences in the ruminal $\mathrm{pH}$ in cows fed the different forages affected uptake. The conditions under which thiomolybdates are absorbed is, however, a controversial subject area; Suttle (2010) proposed that absorption was unlikely unless dietary $\mathrm{Cu}:$ Mo rations were below 1:1, well below the 2.5:1 in our $\mathrm{C}+$ and $\mathrm{G}+$ diets. It is also possible that the added Mo resulted in molybdenosis, however, no characteristic signs such as scouring were noted and dietary values were well below that reported in other studies that have also reported no signs (Raisbeck et al., 2006).

Studies that have fed varying levels of $\mathrm{Cu}$ to dairy cows in the absence of high levels of dietary antagonists have reported little effect on DMI (see review of Sinclair and Mackenzie, 2013); therefore, it appears unlikely that a lower tissue supply of $\mathrm{Cu}$ per se was responsible for the differences in DMI reported here. It is of interest that the inclusion of S and Mo reduced BCS in the cows in our study, irrespective of basal forage level. This effect may be attributed to different mechanisms for each of the forage treatments, as milk yield was higher in cows fed $\mathrm{C}+$ compared with $\mathrm{C}-$, whereas intake was lower in cows fed $\mathrm{G}+$ compared with $\mathrm{G}-$.

The interaction between basal forage source and $\mathrm{Cu}$ antagonists on milk SCC in our study is difficult to explain, although all values were low. The role of $\mathrm{Cu}$ on milk SCC has been demonstrated in dairy cattle in some but not all studies. For example, increasing dietary $\mathrm{Cu}$ concentration from a suboptimal level of 6.5 to $26.5 \mathrm{mg} / \mathrm{kg}$ of $\mathrm{DM}$ was shown to reduce the peak increase in milk SCC following a challenge with Escherichia coli, which was attributed to a greater ability of neutrophils to kill invading bacteria, although the duration of the infection was unaffected (Scaletti et al., 2003). In contrast, dietary $\mathrm{Cu}$ concentration was not shown to have an effect on milk SCC concentration following a challenge with $E$. coli in the studies of Scaletti and Harmon (2012), or when different levels of dietary $\mathrm{Cu}$ were fed (Chase et al., 2000). In our study, cows receiving $\mathrm{G}+$ were in negative $\mathrm{Cu}$ balance, as evidenced by the depletion of hepatic $\mathrm{Cu}$ reserves, whereas all other treatments were in positive balance. It is therefore possible that this lower $\mathrm{Cu}$ status contributed to the increased milk SCC, although other indicators of $\mathrm{Cu}$ status, such as plasma $\mathrm{Cu}$ and plasma $\mathrm{Cp}: \mathrm{Cu}$, were unaffected by dietary treatment. The lower DMI we observed in cows receiving G+ may also have contributed to a greater metabolic stress and indirectly increased milk SCC.

\section{Plasma Mineral Profile, Cu-Mediated Enzymes, and Metabolites}

We found that plasma $\mathrm{Cu}$ concentrations were unaffected by dietary treatment, with all values being above the $9 \mathrm{mmol} / \mathrm{L}$ considered to be adequate (Laven and Livesey, 2005). Our finding is consistent with others that have supplemented $\mathrm{Cu}$ at different levels (Chase et al., 2000), with different levels of dietary $\mathrm{S}$ and Mo (Sinclair et al., 2013), or with different dietary sources of $\mathrm{Cu}$ (Scaletti and Harmon, 2012; Sinclair et al., 2013). In a meta-analysis of the relationship between dietary concentration of $\mathrm{Cu}, \mathrm{S}$, and $\mathrm{Mo}$ and plasma $\mathrm{Cu}$ in grow- 
ing cattle, Dias et al. (2013) concluded that any prediction equation would be limited, and that it is only when animals have either very low or high hepatic $\mathrm{Cu}$ reserves that plasma values can be usefully employed as an indicator of $\mathrm{Cu}$ status (Laven and Livesey, 2005). The plasma $\mathrm{Cp}: \mathrm{Cu}$ ratios reported in our study were generally low and unaffected by dietary treatment. Similarly, we found that plasma SOD, a Cu-containing enzyme involved in the defense against free radicals (Suttle, 2010), was unaffected by dietary treatment. Our findings therefore support Suttle (2010), who suggested that the dietary ratio of $\mathrm{Cu}$ to Mo needed to be close to $1: 1$ before a risk of thiomolybdates causing a systemic impairment of $\mathrm{Cu}$-containing enzymes occurs.

\section{Hepatic Mineral Concentration}

One of the first biochemical changes observed under $\mathrm{Cu}$ deprivation is a decrease in hepatic concentration (Suttle, 2010), as the liver is generally regarded as the principal storage organ for $\mathrm{Cu}$ (Laven and Livesey, 2005). In our study, initial hepatic Cu levels were high and variable at $443 \pm 29.2(\mathrm{SE}) \mathrm{mg} / \mathrm{kg}$ of $\mathrm{DM}$, although most (68\%) animals were below the upper limit of $510 \mathrm{mg} / \mathrm{kg}$ of DM suggested to pose a risk of toxicity (Livesey et al., 2002). The initial mean hepatic $\mathrm{Cu}$ concentration that we found was also lower than that reported by Kendall et al. (2015), where almost $40 \%$ of cull dairy cows in the United Kingdom were reported to have a concentration above $500 \mathrm{mg}$ of $\mathrm{Cu} / \mathrm{kg}$ of $\mathrm{DM}$. As we anticipated, a significant reduction in hepatic $\mathrm{Cu}$ concentration occurred following the addition of dietary $\mathrm{S}$ and $\mathrm{Mo}$, but the greater reduction in cows fed a grass silage- compared with a corn silage-based diet was unexpected, although the difference failed to reach full statistical significance. Suttle (2013) discussed changes in hepatic $\mathrm{Cu}$ concentration that are an exponential function of initial hepatic $\mathrm{Cu}$ concentration, most probably due to a greater rate of biliary excretion at higher liver concentrations. Therefore, we $\log _{\mathrm{e}^{-}}$ transformed and reanalyzed the initial and final hepatic $\mathrm{Cu}$ concentrations to more accurately determine the influence of diet on hepatic $\mathrm{Cu}$ reserves. Similar to the untransformed data, we found no difference $(P>0.1)$ between treatments in initial liver $\mathrm{Cu}$ concentration, but we did find an interaction $(P<0.05)$ between forage source and $\mathrm{Cu}$ antagonist on daily liver $\mathrm{Cu}$ balance $\left(\log _{\mathrm{e}}\right.$ final $-\log _{\mathrm{e}}$ initial), confirming that high dietary concentrations of $\mathrm{S}$ and Mo have a greater effect on $\mathrm{Cu}$ metabolism in cows receiving a grass silage- than a corn silage-based diet.

The influence of forage source on the absorption of $\mathrm{Cu}$ is well demonstrated in sheep (e.g., Suttle, 1983, 2010), and in the absence of high Mo concentrations, the absorption coefficient of $\mathrm{Cu}$ was reported to be 0.014 in grazed grass, 0.049 in grass silage, 0.073 in hay, and 0.128 in leafy brassicas. Our study, however, is the first to report a substantial difference in $\mathrm{Cu}$ status in dairy cows fed corn silage- or grass silage-based rations, but only when S and Mo concentrations were high. Dietary Fe may interact with added S reducing hepatic $\mathrm{Cu}$ concentration (Suttle, 2010). However, the low dietary concentration of Fe in all of our diets compared with that reported for typical dairy cow rations in the United Kingdom (Sinclair and Atkins, 2015) or California (Castillo et al., 2013), in combination with the similarity in dietary $\mathrm{Fe}$ and $\mathrm{S}$ concentration between $\mathrm{C}+$ and $\mathrm{G}+$, does not support $\mathrm{Fe}$ as having a major influence. Consideration should also be given to the lower DMI of cows receiving $\mathrm{G}+$, which resulted in a lower $\mathrm{Cu}$ intake of $49 \mathrm{mg} / \mathrm{d}$ than $\mathrm{G}-$. Nevertheless, at the rate of decline in hepatic $\mathrm{Cu}$ concentration in cows receiving $\mathrm{G}+$, concentrations would reduce and eventually approach the $25 \mathrm{mg}$ of $\mathrm{Cu} / \mathrm{kg}$ of $\mathrm{DM}$ threshold considered to deficient (Laven and Livesey, 2005). In contrast, in cows fed $\mathrm{C}-$ or $\mathrm{G}-$, feeding 20 $\mathrm{mg}$ of $\mathrm{Cu} / \mathrm{kg}$ of $\mathrm{DM}$ would result in a rapid increase in hepatic $\mathrm{Cu}$ concentration, whereas those receiving $\mathrm{C}+$ would be relatively unchanged. Given such large differences in $\mathrm{Cu}$ status when fed the same dietary level, we recommend that forage source as well as dietary $\mathrm{S}$ and Mo concentration should be taken into account when supplementing dairy cows with $\mathrm{Cu}$.

Similar to our previous study (Sinclair et al., 2013), liver Mo concentrations were little affected by dietary treatment, despite a $6.5 \mathrm{mg} / \mathrm{kg}$ of $\mathrm{DM}$ difference in dietary concentration between $(-)$ and $(+)$ treatments, and we can conclude that the liver does not appear to be either a major store or a sensitive indicator of Mo status. Ferritin is the main storage form of $\mathrm{Fe}$ in the body and is particularly concentrated in the liver, where concentrations of between 100 to $1000 \mathrm{mg}$ of Fe/ $\mathrm{kg}$ of DM are considered to be normal in cattle (Suttle, 2010). Hepatic Fe concentrations at the beginning and end of our study were within this range, but, similar to $\mathrm{Cu}$, hepatic Fe concentrations were negatively affected by the addition of $\mathrm{S}$ and Mo, particularly in the grass silage-based diet. In contrast, Phillippo et al. (1987) reported in growing calves fed a barley straw-based diet that an additional $5 \mathrm{mg}$ of $\mathrm{Mo} / \mathrm{kg}$ of $\mathrm{DM}$ increased liver Fe concentrations, which was associated with a decrease in plasma Fe concentrations.

\section{CONCLUSIONS}

Addition of S and Mo had no effect on DMI or milk yield in cows fed a corn silage-based ration, but DMI and milk yield were reduced and milk SCC increased 
when a grass silage-based diet was fed. In the absence of additional $\mathrm{S}$ and $\mathrm{Mo}$, a diet containing $20 \mathrm{mg}$ of $\mathrm{Cu} /$ $\mathrm{kg}$ of DM, whether based on grass or corn silage, supplies well in excess of requirements, as evidenced by the net increase in hepatic $\mathrm{Cu}$ concentration. In contrast, in the presence of high levels of S and Mo, feeding 20 $\mathrm{mg}$ of $\mathrm{Cu} / \mathrm{kg}$ of $\mathrm{DM}$ will result in a rapid depletion of hepatic $\mathrm{Cu}$ concentrations in cows fed grass silage-, but not corn silage-based diets. Within the limits of this study we also found little effect of added $\mathrm{Cu}$ antagonists on plasma $\mathrm{Cu}$ or indicators of plasma $\mathrm{Cu}$ enzyme activity, even at the high levels of $\mathrm{S}$ and Mo, and concluded that use of these parameters to predict $\mathrm{Cu}$ status is limited. Reasons for the differences in $\mathrm{Cu}$ metabolism in cows when fed grass or corn silage based rations is unclear and require further investigation, but our results highlight the importance of taking account of forage source when formulating diets for dairy cows, particularly when dietary S and Mo levels are high.

\section{ACKNOWLEDGMENTS}

The authors are grateful to Agriculture and Horticulture Development Board Dairy (Warwickshire, UK) for funding the work. The technical support of G. Vince and the assistance of N. Atkins at Harper Adams University are also gratefully acknowledged.

\section{REFERENCES}

Agricultural Research Council (ARC). 1980. Nutrient Requirements of Ruminant Livestock. CAB, Farnham Royal, Slough, UK.

AOAC International. 2012. Official Methods of Analysis. 19th ed. AOAC International, Arlington, VA.

Bidewell, C. A., G. P. David, and C. T. Livesey. 2000. Copper toxicity in cattle. Vet. Rec. 147:399-400.

Bray, A. C., and A. R. Till. 1975. Metabolism of sulfur in the gastrointestinal tract. Pages 243-260 in Digestion and Metabolism in the Ruminant. I. W. McDonald and A. C. I. Warner, ed. Univ. of New England Publ. Univ., Armidale, Australia.

Castillo, A. R., N. R. St-Pierre, N. Silva del Rio, and W. P. Weiss. 2013. Mineral concentrations in diets, water, and milk and their value in estimating on-farm excretion of manure minerals in lactating dairy cows. J. Dairy Sci. 96:3388-3398.

Chase, C. R., D. K. Beede, H. H. Van Horn, J. K. Shearer, C. J. Wilcox, and G. A. Donovan. 2000. Responses of lactating dairy cows to copper source, supplementation rate, and dietary antagonist (Iron). J. Dairy Sci. 83:1845-1852.

Cope, C. M., A. M. Mackenzie, D. Wilde, and L. A. Sinclair. 2009. Effects of level and form of dietary zinc on dairy cow performance and health. J. Dairy Sci. 92:2128-2135.

Davies, D. C., and I. H. Jebbett. 1981. Liver biopsy of cattle. In Pract. $3: 14-15$.

Dias, R. S., S. López, Y. R. Montanholi, B. Smith, L. S. Haas, S. P. Miller, and J. France. 2013. A meta-analysis of the effects of dietary copper, molybdenum, and sulfur on plasma and liver copper, weight gain and feed conversion in growing-finishing cattle. J. Anim. Sci. 91:5714-5723.

Dick, A. T., D. W. Dewey, and J. M. Gawthorne. 1975. Thiomolybdates and copper-molybdenum- sulfur interaction in ruminant nutrition. J. Agric. Sci. 85:567-568.
Drewnoski, M. E., S. M. Ensley, D. C. Beitz, J. P. Schoonmaker, D. D. Loy, P. M. Imerman, J. A. Rathje, and S. L. Hansen. 2012. Assessment of ruminal hydrogen sulfide or urine thiosulpfate as diagnostic tools for sulfur-induced polioencephalomalacia. J. Vet. Diagn. Invest. 24:702-709.

Gould, D. H. 1998. Polioencephalomalacia. J. Anim. Sci. 76:309-314.

Gould, L., and N. R. Kendall. 2011. Role of the rumen in copper and thiomolybdate absorption. Nutr. Res. Rev. 24:176-182.

Hart, K. J., J. A. Huntington, R. G. Wilkinson, C. G. Bartram, and L. A. Sinclair. 2015. The influence of grass silage to maize silage ratio and concentrate composition on methane emissions, performance and milk composition of dairy cows. Animal 9:983-991.

Henry, R. J., D. C. Cannon, and J. W. Winkelman. 1974. Clinical Chemistry: Principles and Techniques. Harper and Row Publishers, London, UK.

Jones, D. W., and J. J. Kay. 1976. Determination of volatile fatty acids C-C and lactic acid in silage juice. J. Sci. Food Agric. 27:10051014.

Kendall, N. R., H. R. Holmes-Pavord, P. A. Bone, E. L. Ander, and S. D. Young. 2015. Liver copper concentrations in cull cattle in the UK: Are cattle being copper loaded? Vet. Rec. 177:493.

Kessler, K. L., K. C. Olson, C. L. Wright, K. J. Austin, P. S. Johnson, and K. M. Cammack. 2012. Effects of supplemental molybdenum on animal performance, liver copper concentrations, ruminal hydrogen sulphide concentrations, and the appearance of sulfur and molybdenum toxicity in steers receiving fiber-based diets. J. Anim. Sci. 90:5005-5012.

Krause, K. M., and G. R. Oetzel. 2006. Understanding and preventing subacute ruminal acidosis in dairy herds: A review. Anim. Feed Sci. Technol. 126:215-236.

Laven, R. A., and C. T. Livesey. 2005. The diagnosis of copper related disease, Part 2: Copper responsive disorders. Cattle Pract. $13: 55-60$.

Livesey, C. T., C. A. Bidwell, T. R. Crawshaw, and G. P. David. 2002 Investigation of copper poisoning in adult cows by the veterinary laboratories agency. Cattle Pract. 10:289-294.

Lowman, B. G., N. A. Scott, and S. H. Somerville. 1976. Condition scoring of cattle. ESCA bulletin No. 6.

Ministry of Agriculture, Fisheries and Food (MAFF). 1986. The Analysis of Agricultural Materials. MAFF Reference Booklet 427. HMSO, London, United Kingdom.

NRC. 2001. Nutrient Requirements of Dairy Cattle. 7th rev. ed. Natl. Acad. Press, Washington, DC.

NRC. 2005. Mineral Tolerance of Animals. 2nd rev. ed. Natl. Acad. Press, Washington, DC

Offer, N. W., B. R. Cottrill, and C. Thomas. 1996. The relationship between silage evaluation and animal response. Pages 26-38 in Proceedings of the 11th International Silage Conference. Institute of Grassland and Environmental Research, Aberystwyth, United Kingdom.

Phillippo, M., W. R. Humphries, T. Atkinson, G. D. Henderson, and P. H. Garthwaite. 1987. The effect of dietary molybdenum and iron on copper status, puberty, fertility and oestrus cycle in cattle. J. Agric. Sci. 109:321-336.

Phipps, R. H., J. D. Sutton, and B. A. Jones. 1995. Forage mixtures for dairy cows: The effect on dry-matter intake and milk production of incorporating either fermented or urea-treated whole-crop wheat, brewers' grains, fodder beet or maize silage into diets based on grass silage. Anim. Sci. 61:491-496.

Raisbeck, M. F., R. S. Siemion, and M. A. Smith. 2006. Modest copper supplementation blocks molybdenosis in cattle. J. Vet. Diagn. Invest. 18:566-572.

Richter, E. L., M. E. Drewnoski, and S. L. Hansen. 2012. Effects of increased dietary sulfur on beef mineral status, performance, and meat fatty acid composition. J. Anim. Sci. 90:3945-3953.

Scaletti, R. W., and R. J. Harmon. 2012. Effect of dietary copper source on response to coliform mastitis in dairy cows. J. Dairy Sci. 95:654-662.

Scaletti, R. W., D. S. Trammell, B. A. Smith, and R. J. Harmon. 2003. Role of copper in enhancing resistance to Escherichia coli mastitis. J. Dairy Sci. 86:1240-1249. 
Sinclair, L. A., and N. Atkins. 2015. A survey of dietary levels of selected macro and trace elements fed on UK dairy farms. J. Agric. Sci. 153:743-752.

Sinclair, L. A., K. J. Hart, D. Johnson, and A. M. Mackenzie. 2013. Effect of inorganic or organic copper fed without or with added sulfur and molybdenum on the performance, indicators of copper status and hepatic mRNA in dairy cows. J. Dairy Sci. 96:4355-4367.

Sinclair, L. A., M. A. Jackson, J. A. Huntington, and R. J. Readman. 2005. The effects of processed and urea-treated whole-crop wheat, maize silage and supplement type to whole-crop wheat on the performance of dairy cows. Livest. Prod. Sci. 95:1-10.

Sinclair, L. A., and A. M. Mackenzie. 2013. Mineral nutrition of dairy cows: Supply vs. requirements. Pages $13-30$ in Recent Advances in Animal Nutrition. P. C. Garnsworthy and J. Wiseman, ed. Context Publishing, Ashby de la Zouch, United Kingdom.

Spears, J. W., K. E. Lloyd, and R. S. Fry. 2011. Tolerance of cattle to increased sulfur and effect of dietary cation-anion balance. J. Anim. Sci. 89:2502-2509.

Suttle, N. F. 1974. A technique for measuring the biologival availability of copper to sheep using hypocupraemic ewes. Br. J. Nutr. 32:395-405.

Suttle, N. F. 1983. Effects of molybdenum concentration in fresh herbage, hay and semi-purified diets on the copper metabolism of sheep. J. Agric. Sci. 100:651-656.
Suttle, N. F. 1991. The interactions between copper, molybdenum and sulphur in ruminant nutrition. Annu. Rev. Nutr. 11:121-140.

Suttle, N. F. 2010. Mineral Nutrition of Livestock. 4th ed. CABI, Wallingford, United Kingdom.

Suttle, N. F. 2013. Rates of change in liver copper concentration in cattle given a copper-deficient diet, with or without pre-treatment with tetrathiomolybdate, for evaluation of two parenteral copper supplements. N. Z. Vet. J. 61:154-158.

Suttle, N. F., and M. McLauchlin. 1976. Predicting the effects of dietary molybdenum and sulphur on the availability of copper to ruminants. Proc. Nutr. Soc. 35:22A-23A

Thomas, C. 2004. Feed Into Milk. Nottingham University Press, Nottingham, United Kingdom.

Parliament, U. K. 2012. Animals (Scientific Procedures) Act 1986 Amendment Regulations 2012. The Stationery Office, Norwich, UK.

Van Soest, P. J., J. B. Robertson, and B. A. Lewis. 1991. Methods for dietary fiber, neutral detergent fiber, and nonstarch polysaccharides in relation to animal nutrition. J. Dairy Sci. 74:3583-3597. 